\title{
Олександр Нікілев
}

Дніпровський національний університет ім. Олеся Гончара

\section{Україна у контексті мовної політики держави середини 1940-х - кінця 1980-х рр. (на прикладі Дніпропетровщини)}

Висвітлено процес і проаналізовано причини поширення російської мови і звуження сфери вживання - української в Україні у другій половині 1940-х-1980-х рр. На матеріалах Дніпропетровської області, однієї 3 найбільш аграрно іпромислово розвинутих областей республіки, показано, що викликано це було політикою вищого державно-партійного керівництва СРСР та потужним промисловим будівництвом у перші повоєнні десятиліття у містах області, в ході якого відбувалося широке залучення значних людських мас з різних територій Радянської держави та осідання їх на постійне проживання у містах, що робило об'єктивно прийнятним використання російської мови як мови міжнаціонального спілкування. Поєднання цих двох факторів сприяло масштабному поширенню російської мови у всіх сферах виробничого, адміністративно-управлінського, культурного, повсякденного життя області, міжособистісного спілкування у побуті і на виробництві, визначило русифікацію закладів вищої, середньої спеціальної та професійної освіти, загальноосвітньої школи, дитячих дошкільних закладів. Російська стала для більшості міського населення області мовою повсякденного спілкування. Виявлено, що аналогічні тенденції почали проявлятися і в сільському середовищі. Проаналізовано форми і методи його русифікації. Зосереджено увагу на факторах, що сприяли впродовж зазначеного періоду широкому поширенню $\mathrm{i}$ закріпленню в області російської мови. Серйозний вплив на таку ситуацію мала політика, що почала здійснюватися в СССР після закінчення Другої світової війни за ініціативи секретаря ЦК ВКП(б) А. Жданова. У ході її у республіці відбувся новий спалах репресій, спрямований проти наукової і творчої інтелігенції. Відбувалася вона під гаслами боротьби 3 «плазуванням» перед Заходом, 3 «безрідним космополітизмом», «націоналізмом», «відходом» від марксистсько-ленінського вчення в науці, культурі, мистецтві. Зазначається, що внаслідок такої політики держави область поступово еволюціонувала від переважно монолінгвістичної до білінгвістичної. Показано, що ситуація з перманентним звуженням використання української мови не викликала негативу у населення області. В основі такої його позиції лежали соціально-економічні фактори (краща забезпеченість регіону промисловими і продуктовими товарами, вищі, порівняно з непромисловими регіонами заробітна плата та рівень і якість життя). Звуження мовного середовища української етнічної більшості області свідчило про неорганічність процесів мовної політики у республіці та велику роль партійно-державного керівництва у напрямку саме русифікації регіону. Зазначено, що процес русифікації супроводжувався проявами зневаги до національної історії, культури, сприйняттям всього українського як меншовартісного. Показано демографічні наслідки здійснюваної політики.

Ключові слова: Украӥна, Радянський Союз, Дніпропетровська область, українська мова, мовна політика, русифікація, денаціоналізація, демографічні наслідки

\section{Oleksandr Nikiliev}

Oles Honchar Dnipro National University

\section{Ukraine at the context of the language politics in the middle of the 1940-s - the end of the 1980-s (on the example of Dnipropetrovsk region)}

It was highlighted the process and was analysed the reasons pf spreading Russian language and narrowing the sphere of the using Ukrainian language

in Ukraine in the second part of the 1940s-1980-s. On the materials of Dnipropetrovs'k region, one of the most developed region of the republic in the agrarian and agricultural sphere, it was shown that it was caused by the politics of the highest state-party leadership of the URSR and the most powerful agricultural construction in the first afterwardecade in the region's towns/cities during that the wide-involvement of the significant mass of people happened from different territories of the Soviet state and their subsidence on the permanent residence in the cities that made the using of Russian language objectively acceptable as the language of the international communication. The combination of these two factors contributed the large-scale deterioration of the Russian language in all spheres of production , administrative and managerial, cultural, everyday life and in the production, was identified the russification of the high, secondary special and professional education, general schools, nursery schools. Russian language became the language of the everyday life for the majority of 
the urban population. It was detected that the same tendencies started to appear in the village environment. It was analysed the forms and methods of its russification. The attention is focused on the factors that was promoted the wide-spreading and the fixing of the Russian language in the region. The serious influence on this situation had the policy that began to do in the USRS after the ending of the World War II on the initiative of the secretary of the CPSU Zhdanov A. It was called «zhdanivshchyna». The new outbreak of repression was happened during this period that was directed against scientific and creative intelligence. It was happened under the slogan of the struggle with "crawl" in front of west with "the rootless cosmopolitanism", "nationalism", the departure from marxism-leninism doctrine in science, culture, art. It is indicated that, as a result of such policy of the state, the region evolved from monolingual to bilingual. It's known that the situation with permanent ringing of the using of Ukrainian language didn't wick the negative among the population of the region. This position was based on the socially-economic factors (the best security of the industrial and grocery goods, higher salary compared to non-industrial regions, and the level and quality of life). The narrowing of the language sphere of the most Ukrainian ethnic region testified about the inorganic nature of the processes of the language policy in the Republic and the great role of the party-stare leadership in a sphere of the region russification. It's assigned that the process of russification supervised by the manifestations of anger up to the national history, culture, the perception of everything Ukrainian as less valuable. It's shown the demographic intertance of the carried out policy.

Keywords: Ukraine, Soviet Union, Dnipropetrovs'k region, Ukrainian language, language policy, russification, denationalization, demographic heritage

\section{Постановка проблеми. \\ $\sqrt{\text { попри }} \begin{array}{lrr}\text { овне } & \text { питання } & \text { в } \\ \text { залагодження } & \text { Україні, } \\ \text { иаконодавчому } & \text { рівні, }\end{array}$} не перестає бути одним 3 актуальних чинників суспільної уваги на протязі всіх років іiі незалежності. Проте здебільшого дане питання розглядалося i продовжує розглядатися переважно у політичній площині. Склалося це через те, що воно було, у першу чергу, предметом дискусій на телевізійних ток-шоу представників різних політичних об'єднань, які, залежно від їх партійної орієнтації, стояли або за надання українській мові статусу державної, або надання такого статусу двом мовам: українській та російській. В результаті висвітлення питання у такий спосіб, практично, залишилася поза увагою суть проблеми, а саме історія складання такої ситуації, причини індиферентного iï сприйняття українським суспільством повоєнної доби.

\section{Аналіз публікацій}

I хоча маються праці вітчизняних дослідників з даної проблеми, проте, їх коло невелике та й торкаються вони лише певних iii аспектів. Так, Смольніцька М. приділила увагу проблемам, 3 якими стикалися громадяни УРСР у другій половині 1950 х рр. у своєму бажанні спілкуватися української мовою в публічній сфері (Смольніцька, 2017). Ярмоленко М. розглянула особливості проведення владою мовної політики в УРСР після другої світової війни. Вона показала, що російська мова домінувала у регіонах, які у повоєнний період зазнали значного впливу русифікації (Ярмоленко, 2013). Також проаналізувала мовну ситуацію за часів незалежності, дійшовши висновку, що постійним джерелом напруги в державі у цій царині є мовна біполярність (Ярмоленко, 2012). Бажан О. розглянув ситуацію 3 українською освітою у Криму з часу його приєднання і до кінця 1950-х рр.(Бажан, 2014) та боротьбу громадськості за розширення сфер вжитку української мови в Українській РСР за часів хрущовської «відлиги» (Бажан, 2007). Масенко Л. розглянула мовну політику радянської держави в Україні за весь час перебування республіки у іiї складі, і констатувала домінування російської мови у регіонах, які зазнали значного впливу русифікації (Масенко, 2005).

\section{Мета дослідження}

Тож стан історіографічної ситуації свідчить, що дана проблема ще не стала предметом прискіпливої уваги вітчизняних істориків і значне коло іiі аспектів ще не знайшло свого висвітлення. До їх числа, 
зокрема, належить і такі, як причини, форми i методи поширення російської мови у різних регіонах України у повоєнний період, сприйняття цього процесу їх населенням. Тож недостатнє вивчення даного аспекту вітчизняної історії і визначило вибір теми дослідження, яке проведене на матеріалах однієї 3 найбільш аграрно і промислово розвинутих областей України, що дає можливість розуміння особливостей процесу поширення російської мови в республіці як в цілому, так в регіонах, відмінних між собою за господарським укладом.

\section{Виклад основного матеріалу}

У повоєнний період Дніпропетровська область, як і вся республіка, почала інтенсивно відбудовуватися. У першу чергу - ii промисловість. А це супроводжувалося збільшенням міського населення. За рахунок зростання вже існуючих міст та виникнення - нових (напр. Апостолове, Вільногірськ, Верхівцеве, Жовті Води, Зеленодольськ, Інгулець, Першотравенськ, Покров (до 2016 р. - Орджонікідзе, Придніпровськ) та інші. Урбанізація області супроводжувалася поширенням в ній невпинно і системно у значних масштабах російської мови як мови побутового спілкування, так і офіційної державної мови. В основі цього явища лежала, 3 одного боку, постійна потреба регіону у значних трудових ресурсах для промисловості, яку потрібно було відновлювати та розбудовувати, а 3 іншого - у реалізації державно-партійним керівництвом СРСР, починаючи з 1930-х рр., політки русифікації під виглядом реалізації проголошеного принципу інтернаціоналізму. Відбудова другої половини 1940-х рр. та здійснюване в області у 1950-х та 1960-х у широких масштабах будівництво великих промислових об'єктів різного профілю потребували значних контингентів робочої сили різного профілю та кваліфікації. Для цього сюди централізовано направлялися робочі кадри та спеціалісти з інших регіонів радянського Союзу,упершучергуз Російської
Федерації. Багато людей приїжджали самостійно. У пошуках достойного заробітку, загітовані своїми, уже проживаючими там, рідними і друзями, оповідями про пристойні зарплати, швидке вирішення житлових проблем на новобудовах військовопромислового комплексу, важкої та хімічної промисловості, що вводилися у дію в регіоні, багатий асортимент харчів і невисокі ціни на них тощо. У кінці 1940-х-першій половині 1950-х рр. це були ще й демобілізовані 3 лав Червоної армії, молоді люди різних національностей, призвані до війська під час війни, які, переважно, не мали рідних і домівки у себе на батьківщині, а значить перспектив нормального облаштування свого майбутнього там. Тому їхали на промислові будівництва, де працівники забезпечувалися гуртожиткам, була належна заробітна плата, малися можливості для вирішення своїх життєвих планів. Для багатьох це - завершити перерване війною шкільне навчання і отримати диплом про неповну або повну середню освіту та піти навчатися до технікуму або інституту, для інших - просто мати нормальну роботу 3 хорошою зарплатнею. Як пригадував Гурш Роман Іванович, робітник Дніпродзержинського металургійного заводу, який після звільнення 3 трудового концтабору нацистської Німеччини у 1945 p., приїхав у місто працювати на цей завод, у них у гуртожитку у кінці 1940-х - першій половині 1950-х рр. в основному проживали молоді хлопці з Білорусі, Росії та України, переважно демобілізовані 3 війська і значною мірою - сироти (Гурш, Особистий архів автора).

А в кінці 1950-х - поч. 1960-х pp., у результаті здійснюваного вищим радянським керівництвом скорочення армії і флоту, у значній кількості прибували звільнені 3 неї офіцери зі своїми дружинами, серед яких немало було - іншої національності. Осіли вони переважно у містах. Їхні сім’ї були російськомовними. Та й самі 
скорочені офіцери вже значною мірою були російськомовними. Це було викликане тим, що радянські збройні сили були знаряддям русифікації. Мовою Радянської армії була винятково російська. У політичному навчанні і в навчальних закладах, і в самих військових частинах плекалися традиції винятково російських «героїв». Тож ця хвиля прибулих була додатковою складовою русифікації, що розпочалася в Україні після Другої світової війни. А по суті - була продовжена після перерви, викликаної війною та німецькою окупацією. Просто у повоєнний період склалися об'єктивно умови, що давали вищому партійнодержавному керівництву СРСР можливості реалізовувати ідею впровадження російської мови як державної без проблем. А ситуація в області, через масштабне промислове будівництво та прибуття на новобудови i осідання на постійне життя тут значних мас людей 3 інших регіонів країни, була просто ідеальною. Тому об'єктивно й не могло викликати занепокоєння у місцевого населення та української інтелігенції 3 приводу поширеного вживання російської мови у виробничій і побутовій сферах.

У наступні роки частка звільнених в запас 3 лав радянської армії офіцерів в області продовжувала бути доволі високою. У першу чергу, за рахунок Дніпропетровська. Він входив до числа пріоритетних міст (це, у першу чергу, столиці союзних республік та ще декілька великих промислових міст СРСР) для проживання при виході на військову пенсію офіцерів. Тому що був у промисловому плані один 3 самих розвинутих у СРСР. Рівень життя в ньому, у силу різних причин, і не в останню через високу насиченість підприємствами військово-промислового комплексу, важкої та машинобудівної промисловості, які, через пріоритетність для держави, забезпечувалися товарами широкого вжитку та продовольством незрівнянно краще за багато інших міст. До того ж розташовувався він зручно щодо престижних курортних зон Чорноморського узбережжя. Все це й робило Дніпропетровськ пріоритетним для радянських офіцерів та їхніх сімей осідком для спокійного цивільного життя. Та й проблеми 3 отриманням ними житла тут вирішувалися значно простіше, ніж у столицях. Місто їх забезпечувало новими квартирами і у стислі терміни. Наприклад, у 1960 р., за постановою уряду СРСР, для демобілізованих 3 армії офіцерів було передано із збудованих у Дніпропетровську квартир 25 \%, у 1961 - 45 \%. У 1962 налічувалося ще 500 таких офіцерів, і місто мало виділити їм 25 \% квартир, 3 тих що мали бути здані у тому році (Державний архів Дніпропетровської області. Ф. 416. Оп. 2. Спр.1024. Арк. 35, 36).

Тож щорічно багато офіцерів, і не лише 3 України, при виході на пенсію обирало для постійного проживання саме даний обласний центр. Тож ця категорія демобілізованих, а це були старші офіцери рівня майора полковника,осідаючиумістахобласті,займали керівні посади у різного роду установах міста, а то і очолювали їх, осідаючи разом з рідними у містах області, сприяли поширенню i закріпленню «російськості» у спілкуванні 3 оточуючими, 3 сусідами, 3 колегами по роботі, з підлеглими тощо. I не лише у містах, а й у сільській місцевості. Наприклад, капітан Кучерявий Іван Прокопович, після скорочення 3 лав армії, переїхав 3 дружиною, етнічною росіянкою та іï мамою, вдовою загиблого у роки війни воїна, у адміністративний центр району, де знаходилося його рідне село, смт Щорськ. У стосунках з людьми селища та на роботі він сам і його дружина та теща все життя спілкувалися російською мовою. Дві доньки, хоч і навчалися в селищній україномовній школі, спілкувалися там та й 3 усіма односельцями, і дома з батьками та бабусею, російською. І сам він у сім'ї, говорив російською, а на роботі - переважно російською (Кучерявий, особистий архів автора). 
Іншою складовою мовної ситуації, яка складалася у області, виступала система розподілу молодих спеціалістів до місць їхньої роботи, яка існувала в СРСР. Більшість випускників вищих та середніх спеціальних навчальних закладів розподілялися за межі своїх республік. І це стосувалося переважно випускників трьох республік: Білорусі, Росії та України. Керівництво освітньої галузі СРСР пояснювало таку політику відносно них традиційною відповідальністю молодих спеціалістів 3 цих республік щоᄀдо виконання професійних, посадових обов'язків. Тому значна частина 3 них, на відміну від випускників національних регіонів СРСР, залишалася за місцем призначен $\neg$ ня, закріплювалася там на місцях роботи і тим самим сприяла формуванню місцевих керівних і управлінських кадрів різних сфер економіки та культури. На одній 3 всесоюзних нарад керівників вищих освітніх установ високопосадовий представник міністерства відверто визнав, що така система розподілу викликана небажанням випускників вишів так званих національних республік полишати їхні межі i неможливістю центральних союз органів контролювати процеси направлення i закріплення їх у суміжних 3 цими рес $\neg$ публіками регіонах. Він пояснював, що,

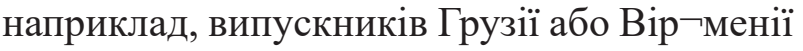
вони не можуть розподілити не те, що на Далекий Схід або у Воᄀлоᄀгодську область, але навіть в республіки Середньої Азії.

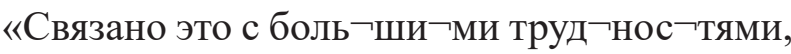
значительно большими, чем при направлении из Украины или РСФСР» (5, арк. 75) і вважав за доцільне здійснювати підготовку в даних респуб ᄀлі ᄀках спеціалістів лише в обсягах їхніх власних потреб, а формування промислово-виробничих керівних та технологічних структур інших регіонів СРСР здійснюᄀвати й надалі за рахунок випускників Ук раїни та Росії (Державний архів Російської Федерації. Ф. 9396. Оп. 5. Спр. 1418. Арк. 75.). Тож випускники російських чи білоруських вищих i середніх спеціальних навчальних закладів які розподілялися на великі промислові підприємства, що зводилися у містах України та Дніпропетровські області у значній кількості (а це у першу чергу Дніпропетровськ, Дніпродзержинськ, Кривий Ріг, Павлоград, Новомосковськ, Першотравенськ, Вільногірськ, Жовті Води, Марганець та інші менші міста) осідали тут i, оскільки отримували професійні знання російською мовою, на виробництві між собою і з підлеглими спілкувалися нею, у повсякденні у сім'ях і з оточуючим говорили цією ж мовою, поширювали і закріплювали у містах традицію вживання російської мови.

Впливало на поширення у промислових центрах області російської мови і таке явище, як повернення додому частини випускників iii навчальних закладів після трирічного обов'язкового відпрацювання за розподілом. І хоча неможливо порахуватипроцент тих, хто повертався після відпрацювання трирічного терміну, проте значна кількість вищих i середніх спеціальних навчальних закладів, які функціонували в області (12 вишів та більше як 150 навчальних закладів середньої спеціальної освіти), свідчить, що обсяги розподілу за межі і області, і республіки були значними. Як приклад можна навести дані по сільськогосподарських інститутах, один 3 яких знаходився і у Дніпропетровську, за період середини 1950-х - середини 1960-х рр. Так, у 1950-х рр. до 50 \% їхніх випускників (а це від 1700 до 1900 осіб) щорічно розподілялося за межі України. До того ж, значною мірою у північні райони Російської Федерації. I лише з початку 1960-х pp. їх відсоток почав поступово зменшуватися 3 35 \% у 1960 р. до 25 \% у 1965 р. (відповідно з 1700 до 767 осіб) (Центральний державний архів вищих органів влади і управління України (далі - ЦДАГОУ). Ф. 1. Оп. 3. Спр. 2447, арк. 2). Пробувши цей час у виробничому та етнічному середовищі, де загальноприйнятим було спілкування 
російською мовою, вони, повернувшись додому, вже продовжували цю тенденцію. Як говорить Махлай Любов Олексіївна, що народилася i виросла у селі МалоОлександрівка Верхньодніпровського району Дніпропетровщини, сформувалася на українській культурі, в україномовному середовищі, яка після закінчення Дніпропетровського механічного технікуму (нині Дніпровський фаховий коледж ракетно-космічного машинобудування) разом з чоловіком, що закінчив фізикотехнічний факультет ДНУ, були розподілені у закрите містечко під м. Арзамас (Росія), де знаходилося виробництво ракетнокосмічної техніки. Все населення того містечка говорило російською мовою. I їм 3 чоловіком вкрай не вистачало спілкування - українською. Проте, повернувшись після майже десятирічного перебування в тому російськомовному повсякденному громадському та виробничому середовищі, вона, як і їі чоловік та дочка, яка народилася там, пішла у дитячий садок, а потім i до школи, вже спілкувалися і в сім'ї, і 3 оточуючими, а тим більше на виробництві (це був Південний машинобудівний завод), лише російською. Тобто українська сім'я вже була повністю російськомовною (Шамрай, особистий архів автора).

У такій мовній ситуації все більше українських сімей у містах області навіть у спілкуванні між собою переходять на російську мову. Особливо у сім'ях, де подружжя закінчували середні спеціальні i вищі навчальні заклади (викладання в них, як по всьому СРСР, відбувалося російською мовою). А також ті, де один 3 подружжя російськомовний, або представник неукраїнської національності i через це мовою спілкування ставала російська. Пресу виписували центральну російськомовну, яка задовольняла потреби всіх членів родини: газети «Правда», «Известия», «Труд», «Комсомольськая правда» (молодіжна)», «Пионерская правда» (для школярів) літературні та літературнопубліцистичні журнали «Москва», «Октябрь», «Ленинград», «Роман-газета». Слухали радіопередачі російськомовні. У таких сім'ях діти виростали в основному російськомовними. Пізніше, вже у створених ними сім'ях, мовою спілкування ставала також російська мова. I для їхніх дітей рідною вже була саме ця мова - мова, яку вони чули в сім'ї зі дня народження, якою 3 ними говорили їхні самі близькі люди, якою користувалися при набутті знань. Тож 3 кожним роком, 3 кожним новим поколінням мовний ландшафт у містах області неупинно змінювався на користь російської мови.

Послідовним провідником такої політики в області були обласні і міські партійнодержавні органи. Все керівництво, весь апарат їх у повсякденні спілкувалися російською мовою. Робочою мовою на проведенні офіційних та публічних заходів, на виробничих нарадах і в міжособистісному спілкуванні працівників цих органів була російська. Вся документація велася російською. А також засідання бюро обласного, міських та районних комітетів партії, сесії районних, міських і обласного виконавчих комітетів рад депутатів трудящих. Документація 3 міськкомів та міськвиконкомів до обласних структур, у Київ, до Москви подавалася російською. Усе, що надходить, - відповідно. Така традиція йшла від партійних і радянських керівників області 3 самого початку звільнення області від німецьких окупантів. Починаючи 3 П. А Найдьонова (очолював обком 3 лютого 1944 - листопаді 1947 рр.), Л. І Брежнєва (листопад 1947 -липень 1950), В. В. Щербицького (листопад 1955 - грудень 1957). Це уродженці Дніпропетровщини, і 3 дитинства жили в україномовному оточенні, самі говорили українською мовою. В усякому разі акцент В. Щербицького зберігся на все життя і свідчив про те, що російською він став спілкуватися на постійній основі лише років 3 17-18, тобто, $з$ початком навчання у 
Дніпропетровському хіміко-технологічному інституті, проте не полишав користуватися й українською. А Л. Брежнєв 3 дитинства мешкав у селі Кам'янському, якому у 1917 р. було надано статус міста, в україномовному середовищі, а в 1920-х-1930-х рр. в анкетах навіть вказував себе за національністю українцем (Кем был по национальности Леонид Брежнев).

Помітне поширення російської мови у всі сферах буття міст області стало спостерігатися вже у 50-х роках. Частина населення почала висловлювати нерозуміння ситуацією, що існувала 3 використанням української мови в її державних установах, вживання російської мови як у спілкуванні службовців, так і у веденні діловодства. Відзначали що саме різного роду посадовці, люди з вищою освітою, керівні працівники в областях, містах і районах виступають перед народом публічно, а також ведуть службові розмови російською мовою, тим самим примушуючи підлеглих звертатися до них російською мовою. Таким чином створювалася традиція звертатися до представників партійних та державних установ російською мовою. Ось як таку мовну ситуацію описував у 1958 р. в листі до газети «Радянська Україна» один з її читачів: «Многие учреждения на Украине переписку ведут на русском языке ... Многие - и в первую очередь руководящие товарищи ... предпочитают русский язык. Украинского языка они стыдятся, отворачиваются от своего народа...» (ЦДАГОУ. Ф. 1. ОП. 24. Спр. 4796, арк. 66-67). Проте керівники обласних, міських та районних партійнодержавних органів були частиною системи і мусили виконувати директиви союзного Центру. Тож основний зміст їхньої діяльності був - беззаперечне додержання «генеральної лінії партії». А до цієї лінії входило і перетворення російської мови на мову «міжнаціонального спілкування». Тож по суті вже $з$ другої половини 1940-х рр., 3 початком масштабного будівництва великих промислових підприємств у містах області і напливу великої кількості неукраїнського населення, поступово але невпинно мовою повсякденного виробничого i побутового спілкування стає російська. Процес русифікації поступово охоплював усі сфери матеріального, суспільного і культурного життя області.

Як результат, у партійно-державних структурах всіх рівнів, підприємствах, комунальних організаціях, в закладах культури, позашкільних дитячих установах - палацах i будинках піонерів, дитячих секторах при клубах, палацах культури, гуртках, спортивних секціях, дошкільних установах їхні працівники на чолі 3 керівниками спілкувалися 3 відвідувачами, зі своїми вихованцями виключно російською мовою. Драматичні гуртки ставили російськомовні виставі. Усі святкові заходи відбувалися російською мовою. Спортивні змагання супроводжувалися російською мовою. Таким чином свідомо чи не свідомо формувалася і закріплювалася у цей період у великих містах області російська мова як мова обслуговування всіляких офіційнокультурних та побутових потреб населення, а в україномовних дітей - звичка говорити 3 оточуючими не українською мовою, якою говорили $з$ дитинства в сім'ях, з близькими i рідними, формуючи таким чином покоління російськомовних громадян міст.

По суті, уже міські дошкільні заклади виступали у ролі вагомого чинника русифікації україномовних дітей уповоєнний період. Як пригадує автор статті, який з 1957 по 1960 рр. перебував у дитячому садку м. Дніпродзержинська, він за цей період не чув жодного українського слова від тамтешніх працівниць: виховательок, нянь, медсестри, завідувачки. Казки всі чотири роки їм читалися лише російські, вірші вчилися лише російські, їхні персонажі були російськими, наприклад - «Дядя Стьопа Вєлікан», «Іван царєвіч», «Альонушка» $\mathrm{i}$ «рратєц Іванушка» тощо. Весь персонал дитячого садка 
говорив і між собою, і з дітьми, і з їхніми батьками російською. Музичний педагог, яка приходила для проведення музичних занять 3 дітьми, лікарка - для проведення медогляду, фотограф, що всі чотири роки робив фотосесії - всі вони і з персоналом і $з$ дітьми говорили лише російською. О. Ф. Нікілєв пригадує, що коли його привела мама до дитячого садка, то у перші ж хвилини, ще стоячи біля неї, відчув щось некомфортне, незвичне для його вуха. I зрозумів, що всі діти між собою спілкувалися лише російською. Він розгубився (навіть складно сформулювати те відчуття) і став роздумувати як йому 3 дітьми говорити. Бо тоді вже відчув, що якою мовою 3 дітьми зразу заговорить, такою мовою й буде 3 ним спілкуватися. Не знайшовши рішення, подумав, що хай буде як буде. I тут же до нього звернулася 3 якимось запитанням дівчинка. Відповідаючи їй, зрозумів, що робить це їй російською мовою. Тож з тих пір і у дитсадку, і в усіх громадських закладах вже завертався до інших російською. Хоча у дворі, у сім’ї, 3 усіма людьми, з яким він до цього говорив українською, продовжив нею спілкуватися. За його спостереженнями, у всякому разі не менше половини дітей його групи, як i він сам, були україномовними і говорили дома українською (Нікілєв, особистий архів автора).

Серйозним фактором русифікації міст області стала школа. Як загальноосвітня, так і вища та середня спеціальна. Попри те, що після війни в області ще продовжилася тенденція розвитку української освіти. Проте вона мала всі ознаки поступового затухання. Так, ще було немало сімей, навіть у обласному центрі - найбільш зрусифікованому місті регіону, де за українською традицією діти до батьків продовжували звертатися на «Ви». Для основної частини населення міст рідною мовою продовжувала бути українська (Безручко, особистий архів автора). Мало місце навіть зростання в них мережі україномовних шкіл. Наприклад, у Дніпропетровську за період 3 1946/47 н. р. по 1957/58 н. р. кількість шкіл 3 українською мовою навчання збільшилася на 7: $з 22$ до 29 шкіл, при скороченні їх у абсолютній більшості обласних центрів. Навіть у Львові. Правда при цьому одна українська школа, а саме 7-річна школа № 19 у 1956 р. була закрита (ЦДАГОУ. Ф. 1. Оп. 31. Спр. 369, арк. 62-63). Але при цьому зростання російських було у двічі більшим - на 15. До того ж кількість їх у місті була значно більшою - 40 у 1946 p. і 65 у 1957 p (ЦДАГОУ. Ф. 1. Оп. 24. Спр. 4796, арк. 51). Разом зі збільшенням російськомовних шкіл зростав і кількість учнів у них. Так у 195859 н. р. у Дніпропетровську в українських школах навчалося 11,1 тис. учнів, а у російських - 52,3 тис., що у процентному відношенні становило $17,4 \%$ та $82,6 \%$ відповідно (Русифікація України). Шкільні програми предметів, що викладалися, також у цей період зорієнтовується на зближення 3 російськими програмами. Наприклад, Історія СРСР і Історія Української РСР i структурно, i за наведеним фактажем були близькими. Перший розділ кожного 3 підручників розглядав історію від давньої доби i до татаро-монгольської навали та падіння Києва. А наступний - починався вже 3 періоду «Національно-визвольна боротьба українського народу проти Польщі». При такому підході до викладення матеріалу випадали 400 років історії України. У результаті, українські учні не знали про Галицько-Волинське князівство, яке продовжило більш, ніж 150-річне існування державності на українських землях, історію перебування українських земель у складі Великого князівства Литовського а пізніше - Речі Посполитої, про успішні дії українців - військових і політичних діячів цих держав у боротьбі з Московським князівством, про культурний розвиток українських територій у цей період, про внесок іiі представників у європейську науку i культуру. Розділи, присвячені висвітленню подій нової i 
новітньої історії, також вкрай обмежено подавали події власне української історії. Наводилися переважно фактаж російський, a по післяреволюційних періодах загальносоюзний. Тож значні пласти українськоївійськової,політичної, соціальної історії залишалися бути невідомими для учнів. У них відбувалося формування гордості не за Україну, а за Радянський Союз. А на підсвідомому рівні це поширювалося на Росію, як державоутворюючу країну що за часів імперії, що за часів СРСР. Фактично виходило, що вони вивчали і знали історію переможців 3 точки зору переможців i сприймали їі за свою.

Аналогічна ситуація мала місце і при викладенні української мови і літератури. Так, правила українського правопису перманентно наближали до правопису російського. 1961 p. набув чинності «Український правопис 1960-1961 pp. (четверта редакція)», де «українські правила» наближено до «Правил російської орфографії та пунктуації», що вийшли друком 1956 p. Вивчення творчості українських поетів і письменників відбувалося значною мірою формально. Коло їх було доволі вузьке, як і коло їхніх творів, затверджених для опанування учнями. У результаті формувалося сприйняття школярами української літератури як меншовартісної порівняно $з$ російською, не цікавої і вони віддавали перевагу у читанні саме російським письменникам, формуючи звичку читати російських авторів і звикаючи сприймати описувані події через російську мову.

Аналогічні тенденції мали місце і в освітніх установах інших рівнів. Професійні знання у навчальних закладах від профтехучилищ, технікумів до вишів професійні знання надавалися лише російською мовою. Вступні екзамени до них проводилися російською. А 31954 р. знання української мови взагалі перестало бути обов'язковою вимогою при вступі до вишів республіки. Таким чином, вступники 3 Російської Федерації мали значно більші шанси витримати вступні іспити, ніж молодь, рідною мовою якої була українська. До прикладу, у 1955 р. на перший курс медичних та фармацевтичних ВНЗ України із загальної кількості абітурієнтів вступали 29,2 \% - абітурієнтів проживаючих на території республіки, 26,8 \% - з РСФСР і до 47,7 \% - проживаючих в інших союзних республіках (Шевченко, 2014, с. 835).

Таку ситуацію бачило немало мешканців області і вона їх тривожила. Ось як 3 цього приводу писав у 1958 р. до газети «Радянська Україна» один з іiі дописувачів: «Батьки-українці стали віддавати своїх дітей до російської школи. ..., юнак, що виховався в українській родині і скінчив українську школу прагне вступити до інституту. Але в більшості інститутів і технікумів навчання проводиться російською мовою. Екзамени теж необхідно складати з російської мови і російської літератури. Ясно, що цей юнак не може конкурувати 3 тими, хто вчився в російських школах, чи росіянами. Тому батьки-українці і прагнуть будь-що віддати дитину до російської школи» (ЦДАГОУ. Ф. 1. Оп. 24. Спр. 4796, арк. 64).

Тож уже у 1950-х рр. стає обов'язковою ознакою людини 3 вищою чи середньою спеціальною освітою іiі російськомовність на роботі та у громадських містах. Це для людей була ніби ознака освіченості, «культурності», «інтелігентності», статусності, приналежності «начальства». По суті тогочасна суспільна атмосфера примушувала до цього. Ось як таку ситуацію описує до газети «Радянська Україна» у 1958 р. один зі студентів: «Мені часто говорять товариші: «Ти скоро будеш інженером, а говориш українською мовою». Хіба щоб стати спеціалістом треба неодмінно забути свою мову? Реальна дійсність відповідає: «Так». ... Я хочу вчитись на своїй мові, хочу працювати, користуючись своєю мовою, але чим настирливіше я домагаюсь свого, тим 
більше на мене дивляться як на дивака, я ... бував в Харкові і в Дніпропетровську, іте саме: у всіх вищих школах викладають російською мовою» (ЦДАГОУ. Ф. 1. Оп. 24. Спр. 4796, арк. 62-63). Те, що така ситуація була вже нормою свідчив й інший, російськомовний, дописувач, який у своєму листі до газети у 1958 р. $з$ осудом відзначав, що «...в пределах Украины многие высшие учебные заведения для украинцев ведут обучение на русском языке. ...» (Смольницька, 2014, с. 122).

Паралельно з закладами освіти, дитячого дошкільного та позашкільного виховання, партійно-державними, культурно-освітніми установами, промисловими і комунальними підприємствами процес русифікації здійснювався й через радіо, телебачення, пресу. У квітні 1958 р. розпочав свою роботу телевізійний центр у Дніпропетровську. Проте, роль його по суті зводилася до функцій ретранслятора. Основна маса передач здійснювалася з Москви, а значить - російською мовою. Невелику частку становили передачі 3 Києва. Це були виступи колективів народної творчості республіки, республіканські новини, вистави українських театрів. Зовсім мізерну частку становило обласне мовлення. Проте воно зводилося лише до передачі обласних новин та оголошень про набір на роботи. Тож і в селі, і в містах люди були зорієнтовані на російськомовний контент. Адже він містив, окрім новин, і кінофільми, і концерти, i виступи відомих артистів тощо (і всі вони транслювалися російською мовою, до якої вже у сім'ях з малечку долучалися і міські, i сільські діти). У наступні десятиліття дещо розширився мовний формат обласного i республіканського телецентрів, проте пропорції залишалися ті ж, що раніше. А московські передачі, через значно краще фінансування ставали більш привабливими і користувалися більшою популярністю як у міського, так і у сільського населення.

Стосовно радіо, то ситуація була аналогічною. Хоча на радіо в сільській місцевості в основному була українська мова (лише деякі: новини з Москви, дитячі та літературні передачі, транслювалися російською), там основним було радіорелейне мовлення, де була лише одна програма - республіканського та обласного радіомовлення. I хоча й намагалася вона задовольнити потреби всіх категорій сільського населення, проте це зробити було не можливо. Так, з музичних була лише «Від суботи до суботи», яка транслювала пісні на замовлення, популярні у населення, значна частина яких була на російській мові. У місті широко були поширені радіоприймачі, які давали можливість самостійно шукати радіопрограми. А цікаві були в основному російськомовні передачі 3 Москви. Як приклад цілодобова музично-інформаційна «Маяк» та молодіжна музична - «Юность», що виходила в ефір з 15 до 21 години вечора по непарних годинах впродовж робочого тижня, а також щонедільна розважальна «С добрым утром». Для малят була - «Радио няня», для школярів - «Пионерская зорька».

3 телевізійних найбільш популярною була музична передача - «Голубой огонек» («Блакитний вогник») - музикальнорозважальна програма, яка почала виходити в ефір з квітня 1962 р. Довгий час транслювалася щонеділі. В ній брали участь відомі виконавці опери, балету, цирку, естради, а також почесні гості - космонавти, видатні військові діячі, представники науки, мистецтва, відомі спортсмени. 31964 p. «Голубой огоньок» став традиційною щорічною новорічною передачею на радянському телебаченні. Тож люди всієї країни з нетерпінням чекали їі і з захопленням дивилися. Українське телебачення у такій системі подачі матеріалу користувалося, особливо у підростаючого покоління, значно меншою популярністю. Та й передач цікавих там було мало.

Серйозний вплив на таку ситуацію мала політика, що почала провадитися в СССР після закінчення Другої світової війни за 
ініціативи секретаря ЦК ВКП(б) А. Жданова, яка отримала назву «ждановщина». В ході іiі у республіці відбувся новий спалах репресій, потужний удар яких зазнала науково-технічна i творча інтелігенція. Усе це проходило під гаслами боротьби 3 «плазуванням» перед Заходом, 3 «безрідним космополітизмом», 3 «відходом» від марксистсько-ленінського вчення в науці, культурі, мистецтві.

За період іiї реалізації, а це з 1946 по 1951 pp., ЦК КП(б)У було видано 12 постанов 3 ідеологічних питань. Вони стосувалися літератури, літературних журналів, репертуару драматичних і оперних театрів, музичного мистецтва, підручників з історії України, ідеологічної роботи з населенням. В них містилися звинувачення української інтелігенції у націоналізмі, «відступі від партійного розуміння мистецтва», заклик до боротьби 3 тими, хто відійшов від радянської ідеології, та до необхідності «розгортання більшовицької критики i самокритики». Почалися переслідування i звинувачення в «націоналізмі» цілого ряду провідних українських письменників, композиторів, науковців, у тому числі й істориків. Їх звинувачували у «націоналістичних збоченнях», «численних помилках», перекрученнях «буржуазнонаціона-лістичного характеру», відсутності показу великої ролі російського народу, у «низькопоклонстві перед Заходом». Це вело до ігнорування досягнень західних країн у всіх сферах, перебільшення успіхів радянської держави, зростання взаємної недовіри, догматизму, підозрілості і головне - посилення російського шовінізму і процесу русифікації. Адже положення цих постанов через засоби масової інформації (радіо, газети, журнали) активно поширювалися. Таким чином здійснювалася активна ідеологічна обробка населення. І це впливало на свідомість радянських людей.

Тож в області, як і в республіці в цілому, у творчих об'єднаннях художників, композиторів, письменників (обласних спілках), у вищих та середніх спеціальних навчальних закладах після виходу кожної з 12 постанов проводилися багатогодинні закриті партійні збори, на яких «виявляли» своїх колег, що підпадали під їхні (постанов) положення, i звинувачували їх чи то у «низькопоклонстві перед іноземщиною», чи то у «безродному космополітизмиі», як ряд працівників редакцій обласних газет «Зоря» та «Днепровская правда» (Поляков, 2018, с. 216), чи то у наданні «відвертої пропаганди в лекціях переваг німецько-фашистської науки i культури», або у дотриманні «аполітичної безпартійної науки», як, наприклад на філологічному факультеті Дніпропетровського державного (нині Дніпровського національного) університету (Поляков, 2018, с. 215).У вересні 1947 р. у партійних організаціях усіх вищих навчальних закладів області були проведені збори, де було заслухано про ситуацію зі ставленням до Заходу їхніх викладачів. Було «виявлено», що у цілому ряді вишів, у тому числі у гірничому, фармацевтичному інститутах, державному університеті викладачі «читаючи лекції, користуються іноземними джерелами, часто незаслужено популяризують праці іноземних вчених і зовсім недостатньо висвітлюють роль вітчизняних вчених у розвитку світової науки і техніки» (Поляков, 2018, с. 215). Ці люди отримали негативні характеристики своєї професійної діяльності. У 1947 р. на партзборах ДДУ була піддана критиці група викладачів і наукових працівників фізикоматематичного факультету. Наприклад, один 3 професорів фізико-математичного факультету був звинувачений у невизнанні авторитету радянських науковців бо нібито «свій підручник написав, спираючись на дослідженнях зарубіжних вчених», а один 3 лаборантів факультету «3 відвертим презирством ставився до приладів вітчизняного виробництва, завжди протиставляючи їм усе закордонне». А на філологічному факультеті ряд викладачів 
були звинувачені у фактах «відвертої пропаганди в лекціях переваг німецькофашистської культури і науки» і відсторонені від викладацької діяльності (Поляков, 2018, с. 215). У 1948 р. партбюро ДДУ розглядало ситуацію на біологічному факультеті, НДІ біології та Ботанічному саду. В результаті було визнано ряд їхніх викладацьконаукових працівників такими, що «не мали ідейних поглядів» i «не викликали політичної довіри», за що були звільнені 3 роботи (Поляков, 2018, с. 216-217).

Така ж ситуація мала місце на філологічному факультеті університету. У березні 1949 р. партком ДНУ виявив там ряд «буржуазних націоналістів» та «безродних космополітів» (Поляков, 2018, с. 216). У результаті багатогодинного обговорення i звинуваченняїх в цьому, декількох викладачів було виключено 3 партії, декільком винесено партійну догану, а завідувача кафедри знято з посади (Поляков, 2018, c. 217). На історичному факультеті того ж року партійним комітетом університетської організації було проведено збори з проблеми боротьби 3 космополітизмом. По їх результатам було виявлено ряд викладачів, що мали «серйозні методологічні помилки», «читали лекції у дусі буржуазного об’єктивізму», «занедбали принципи більшовицької партійності». Ідеї викладачів творчого характеру були протрактовані на рівні кримінальних злочинів. Наприклад, такі, як об'єктивна оцінка І. Бєлінського як учня західноєвропейських філософів, а не як видатного російського філософа (яким він ніколи не був і сам себе не розглядав), або оцінка П. Я. Чаадаєва як людини $з$ широким мисленням. За ці і подібного роду думки було винесено суворі догани ряду викладачів, а одного - було звільнено з роботи. При цьому було ліквідовано навіть діючій при факультеті музей, тому що його створив один зі звинувачених викладачів (Світленко, 2020, c. 55-56).

Тодішню задушливу атмосферу передала у своїх спогадах професор Дніпровського національного університету I. Ф. Ковальова, яка саме у описуваний період навчалася в ДДУ. «Університет тих років був зліпком загальнодержавної системи ідеологічного диктату... Через нас прокочувалися хвилі ініційованих ЦК кампаній 3 боротьби 3 космополітизмом, «вейсманізмом-морганізмом» (генетикою О. Н.), «продажною дівкою імперіалізму кібернетикою та ін. Брутальний тон дискусії iз наперед визначеними висновками, безпардонне цькування, що ініціювалося вчорашніми друзями та колегами, залишали вкрай важке враження...» (Ковалева, 2008, с. $65)$.

Тож студенти впродовж всього періоду навчання бачили на долі викладачів i відчували на собі «важку руку» радянського керівництва стосовно тих, хто на його думку, відступав від «лінії партії». Адже чи не кожного тижня їм доводилося приходити на комсомольські збори, а студентамкомуністам, ще й - на партійні, в ході яких вони були змушені критикувати одне одного. Такі повсякденні реалії навчально-виховного процесу впливали на рішення багатьох з них бути більш прихильним до російства. Адже вонибачили, якзвільнялиз роботивикладачів, звинувачених у «космополітизмі», тобто у відсутності показушної демонстрації любові до російського чи радянського або у «націоналізмі», виносили суворі партійні догани, що негативно впливало на подальшу кар'єру людей, їх особисте життя. Як зовнішній прояв - переходити на спілкування 3 оточуючими на російську мову, віддавати пріоритет російській культурі як якісно вищій порівняно 3 іншими культурами у тому числі і вищою, ніж культури інших народів СРСР, зокрема й українського.

Таким чином, у другій половині 1940-х-1950-х pp. у містах області спостерігався процес поширення російської мови у всіх сферах. Викликаний він був як ідеологічною повоєнною політикою 
вищого державно-партійного керівництва CРСР, так i потужним промисловим будівництвом у містах області, в ході якого відбувалося широке залучення значних людських ресурсів 3 різних територій країни, що робило об'єктивно прийнятним використання російської мови як державної мови країни, яку всі вчили в школі і яку всі розуміли. Торкнувся він усіх соціальних категорій ¥іi населення. Намітилася i закріпилася тенденція зменшення мережі шкіл з українською мовою викладання i, відповідно, зменшення кількості молоді, яка вивчала українську мову й активно нею користувалася у повсякденні. Натомість, збільшувалася мережа шкіл 3 російською мовою викладання і зростала кількість сімей, які віддавали перевагу у виборі російської мови для навчання своїх дітей. Почало закладатися у свідомості людей сприйняття української мови як мови меншовартісної. По суті українська мова як мова повсякденного вжитку як у побути, так i на виробництві у містах почала втрачати свої позиції і продовжила функціонування лише у селі.

Особливо ці тенденції посилилися починаючи 3 1960-х рр. Сприяло цьому проведення у кінці 1950-х - поч. 1960-х pp. реформи середньої освіти. Важливою іiі складовою був закон Верховної Ради СРСР 1959 р. «Про зміцнення зв'язку школи 3 життям і про дальший розвиток народної освіти», на підставі якого інтенсивно посилено русифікацію українського шкільництва. Одним 3 його положень був дозвіл у російських. школах республіки, за заявою батьків, звільняти їхніх дітей від обов'язкового вивчення української мови i літератури. При тому що російська, як i всі інші предмети, була обов'язковою для вивчення (Радянська Україна. 1959. 19 квітня. №92, с. 2-3). Переважна більшість батьків, значна частина яких були україномовними, щоб в майбутньому полегшити своїм дітям вступ до навчальних закладів, де екзамені та все навчання відбувалося російською мовою, обирали в школах великих міст, як правило, російську мову викладання. Внаслідок такої мовної політики в наступні роки в області, як і в республіці загалом, розпочалося неухильне зменшення кількості українських шкіл.

Посприяло цій тенденції, таке, вкрай позитивне соціально-економічне явище, як масове житлове будівництво, розпочате за часів хрущовської «відлиги». Нові житлові райони заселялися представниками різних національностей. Значну частину ï становили працівники 3 промислових новобудов міст, що переїхали на роботу 3 інших республік. У нових житлових районах школи, що відкривалися, вже були російськомовними. Усі покоління їхніх учнів вже спілкувалися і в школі, і поза нею російською мовою. Тож нові райони міст, а спочатку у Дніпропетровську, Дніпродзержинську, Кривому Розі це були «Черемушки» (пізніше зводжувальні отримували вже індивідуальні назви), були російськомовними. У центрі міст, здавна функціонуючі просвітні установи, також змінили свій статус. Адже в центральній частині їх мешкали у переважній більшості їхні очільники, керівники і працівники партійно-державних органів, культурноосвітніх установ, керівники підприємств та організацій, тобто всі ті, для кого російська була мовою офіційного i побутового спілкування. Українські школи продовжили своє функціонування лише на периферії міст. Але й вони, попри назву і викладання більшості предметів українською мовою, по факту поступово стають російськомовними, тому що і діти і викладачі говорять вже і між собою, і на перерві, а не рідко й на уроках, так як звикли за звичай говорити, тобто лише російською. Уже у 1965 р. у своїй праці «Націоналізм чи русифікація» I. Дзюба показав реальний масштаб такої ситуації «... ті школи, які називаються українськими, по суті ними не є... поза викладанням усе 
внутрішне життя ведеться в них російською мовою навіть самі вчителі по-українському «соромляться» говорити, не говорячи вже про учнів..... Але найгірше те, що «українські» школи.... зовсім не виховують національну гідність і національне почуття, не дають елементарного усвідомлення своєї національної приналежності та рідної культури... Бо в більшості з них панує дух вищості і «предпочтительности» російської культури та другорядності української...» (Дзюба, 2005, с. 175). У діючих же російськомовних школах з'являються випадки звільнення батьками своїх дітей від вивчення української мови та літератури. 3 цього приводу В. Стус, працюючи ще вчителем на Донеччині, у 1962 р. писав поету А. Малишку: «... читати українську мову в російській школі - одне недоумство. Треба мати якісь моральні травми, щоб це робити. Одна усна заява батьків - і діти не будуть вивчати мови народу, який виростив цих батьків, хіба це не гопашний театр - 3 горілкою i шароварами? Обов'язково німецьку, французьку, англійську мову, крім рідної...» (Цит. по Баран., Даниленко, 1999, с. 118). Хоча в 1960-х рр. такі випадки зустрічалися ще лише як виключення (для дітей, чиї сім'ї переїхали з інших регіонів СРСР і які не знали української), у наступні два десятиліття це набуло все зростаючих масштабів.

Іншим важелем посилення русифікації, що несла з собою реформа, було створення такого виду навчальних закладів, як школиінтернати. Організацією цього виду освітньовиховних установ держава суттєво допомогла малозабезпеченим та багатодітним сім'ям дати своїм дітям повноцінну середню освіту. А таких було багато у сільській місцевості, де заробітна плата була у колгоспників помітно нижчою, ніж у жителів міста, а сім’ї мали по три та більше дітей. Тож таке нововведення держави суттєво допомагало багатодітним і малозабезпеченим сім'ям у наданні їхнім дітям належного рівня освіти та в результаті цього - отримання ними належної професії. Автор добре пам'ятає, як у першій половині 1960-х рр., коли вони з мамою відправлялися по понеділкам ранковим поїздом зі станції Божедарівка біля смт Щорськ (нині - Божедарівка Криничанського р-ну) додому до м. Дніпродзержинська (нині Кам'янське), до станції завжди під'їжджало по декілька підвод з навколишніх колгоспів, в кожній з яких сиділо по декілька хлопчиків і дівчаток, що їхали на навчання на тиждень у такий інтернат у Дніпродзержинську (Нікілєв, особистий архів автора).

Але водночас така новація посилила процес русифікації села як республіки в цілому, так i області Адже перебування 5-6 днів на тиждень впродовж навчального періоду цілорічно у російськомовному середовищі навчального закладу, сприяло тому, що їхні вихованці поступово переходили на російську мову спілкування, а 3 часом і на мислення російською мовою (адже викладанням предметів відбувалася російською, у а позашкільний час викладачі, вихователі та адміністрація спілкувалися 3 ними цією ж мовою). I таким чином ставали вже носіями російської мови.

Вагомим чинником посилення русифікації села області була і наявність в іiі містах великої кількості професійнотехнічних училищ (iх у той час молодь зверхньо називала - «бурси»), які давали виробничі професії і готували робітничі кадри для тієї великої кількості промислових підприємств та будівельних організацій, що визначали область у республіці як промислову. Саме в них навчалася значна кількість учнів сільських шкіл - семирічок, які через нижчу якість надання освіти, обмежували можливості сільським дітям поступити до технікуму та отримати середню спеціальну освіту, а тим більше - вищу. Тож україномовні сільські діти йшли значною мірою до «бурс», після закінчення яких у переважній більшості починали працювати на промислових підприємствах області i 
у спілкування на роботі та у повсякденні, демонстрували вже свою, так би мовити, вищевартісністьламаною російською мовою. Про цю прикру ситуацію писав I. Дзюба: «Школи ФЗН, ремісничі та інші училища. В них набирається переважно сільська молодь і протягом кількох років зазнає нещадного мовного калічення» (Дзюба, 2005, с. 121).

Аналогічна ситуація мала місце, хоч і в менших масштабах, через меншу кількість там вихідців із села, серед студентів середніх спеціальних та вищих навчальних закладів. Навчання там провадилося російською, поза заняттями викладачі та адміністрація гуртожитків 3 ними спілкувалися лише російською. Практично більшу частину доби вони знаходилися у російськомовному оточенні. Таким чином поступово природнім шляхом самі починали переходити на російську. Тож приїжджаючи на вихідні та канікули у розмовах $з$ друзями, що мешкали у селі, часто демонстративно розмовляли російською, щоб підкреслити свій відмінний вже статус чи то освітній, чи соціальний, чи «культурний», оскільки вони вже «городські». Багато хто у процесі навчання переходив вже на спілкування і з рідними на російську. Таку картину доводилося у середині-другій половині 1960-х рр. спостерігати автору, коли він приїжджав до своєї бабусі у село. Особливо ці зміни по ставленню до своєї рідної мови можна було бачити у суботу і неділю, коли багато 3 сільських дітей, що навчалися у місті, приїжджали додому і в своєму молодіжному середовищі демонстрували тим, хто або не поїхав до міста і продовжував працювати і жити у селі, або ще навчалися у школах, свою «приналежність до міста», постійно у розмові з ними вживаючи російські фрази.

Тож, у 1960-х рр. процес русифікації в області, як і у всій Україні, посилюється. У наступні десятиліття, особливо після зняття у 1972 p. П. Шелеста з посади першого секретаря ЦК КПУ, поширення переходу до російської мови у всіх сферах життя області пришвидшується. Посилюється процес русифікації освіти. 1973 р. в «Основах законодавства Радянського Союзу та союзних республік про народну освіту» ще раз було зазначено, що вивчення мови національних республік в їх російськомовних школах. У 1978 р. була видана постанова ЦК КПРС про посилене вивчення і викладання російської мові літератури, у 1983 - постанова про посилене вивчення російської мови, поділ класів в українських школах на дві групи та підвищення заробітної плати вчителям російської мови на 15\% (Українська мова в СРСР). У містах області практично зникли вивіски українською мовою на крамницях, кіноконцертні афіші були виключно російською мовою і фільми, навіть зняті на українських кіностудіях, i значить такі, що за тогочасним положенням мали бути україномовними, демонструвалися російською. Доповіді, публічні лекції, читалися також російською, всі культурно-масові та громадсько-політичні заходи відбувалися російською мовою (Смольніцька, 2014, с. 120). Як на офіційному, так і в міжособистісному спілкуванні різних соціальних, професійних, вікових категорій населення, а головно серед молоді, мовою спілкування стала російська. У їхній свідомості все міцніше закорінювалася переконаність у вищевартісності російськості. Така ситуація ще більше сприяла пониженню статусу української мови у підростаючого покоління міських жителів, їхніх батьків, багатьох громадян області.Продовжуєтьсяневпиннескорочення кількості україномовних шкіл. Процес скорочення їх тривав до кінця 1980-х рр. Одним із яскравих показників цього процесу $€$ дані про чисельність шкіл з українською й російською мовами викладання та мішаних (російсько-українських) у Дніпропетровську на середину 1987 р. Зі 140 функціонуючих на той час у міліонному місті навчальних закладів було лише 9 українських шкіл, ще 6 офіційно вважалися змішаними, інші ж 
125 були російські (https://uk.wikipedia.org/ wiki/Шкільництво_в_Україні).

Українські середні загальноосвітні заклади ліквідовувалися як такі, що не мали належної кількості контингенту та перепрофільовувалися, або у повному складі вчительські колективи та учнівські контингенти переводилися у новозбудовані поблизу російські школи. Типовий приклад - СШ №15 у Дніпродзержинську. Вона була споруджена в кінці 1940-х рp. у новозбудованому районі, як українська школа, а на поч. 1980-х рр., через хронічну роками невідповідність нормам кількість учнівського контингенту, була переведена у новозбудовану неподалік російськомовну школу №3. А в іiї приміщенні було відкрито кулінарне училище, де викладання також відбувалося російською.

Звуження сфери вживання української мови проявлялося i зовні. 3 часом абсолютна більшість вивісок на крамницях, закладах харчоторгу, освітньо-культурних установах, підприємствах та організаціях, адміністративних спорудах, назв вулиць, населених пунктів (навіть у сільській - україномовній місцевості) тощо вже пишеться лише російською мовою. Російською мовою велися усі справи партійного, державного i громадського життя, всі галузі культури, господарської сфери та їхнє діловодство, вища, середня технічна і професійна освіта.

3 1960-х років вже народжуються покоління, що росли переважно у сім'ях, де мовою спілкування була російська. Тож для них, попри те що люди вважали себе українцями, рідною вже була російська, а не українська, як для їхніх мам та бабусь. У містах області стало нормою вже не лише в офіційних установах, у громадських місцях, у транспорті, а й на міжособистісному рівні, у побуті говорити російською. Тож молоді спеціалісти носії української мови, що розподілялися у міста області 3 україномовних регіонів, наприклад
Галичини, Буковини, Закарпаття, змушені були переходили на російську мову на виробництві, а з часом і в сім'ях. Осідаючи в області чи в інших регіонах Центральної i Східної України вони змушені були переходити на російську мову i це поступово закріплювалося і ставало вже звичкою у спілкуванні як на виробництві, так і у повсякденному житті.

У цей же період відбувається процес русифікації невеликих міст та селищ міського типу області, які виникали у XУІІІ-ХІХ століттях як українські села, а у XX - у результаті розвитку економіки краю набували промислового значення i отримували відповідний статус. Це i Апостолове, і Божедарівка, і Вільногірськ, і Верхівцеве, і Жовті Води й ряд інших. У них населення вело спосіб життя і мало менталітет властиві сільським поселенням. Мовою повсякденного спілкування та діловодства там була українська. Але під впливом появи там промислових підприємств, носіїв російської мови в них: керівників підприємств i організацій, їх інженерно-технічного персоналу, молодих спеціалістів, що розподілялися туди на роботу після закінчення навчального закладу, які у побуті та на виробництві вже говорили виключно російською, тут також починає спостерігатися поширення російськомовності. Там у школах уже починають відкривати російськомовні класи. Спочатку по одному. 3 роками набираючи тенденцію до збільшення. Л. О. Шамрай, яка отримала середню освіту у м. Верхівцеве у другій половині 1960-х рр, пригадує, що після закінчення восьмого класу, їй, як і частині інших восьмикласників, не вистачило місця в українських класах Верхівцівської школи, тож дітей зарахували до російськомовного класу, де місця були (Шамрай, особистий архів автора).

Така ситуація 3 перманентним звуженням використання української 
мови не викликала занепокоєння у батьків учнів та й взагалі у населення області. Вона сприймалася через призму людських оцінок процесів, що відбувалися в області, які формувалися у першу чергу соціальноекономічними чинниками (високий ступінь промислового розвитку регіону, краща його забезпеченість промисловими i продуктовими товарами, вищі, порівняно 3 непромисловими регіонами заробітна плата та рівень і якість життя). Адже все населення знало, розуміло українську мову, добре говорило російською і це сприймалося дуже позитивно всіма. Тож і не викликало ніяких нарікань. Проте, при цьому не бралося до уваги і не помічалося, що процес урбанізації та потужне промислове будівництво супроводжувалося широким поширенням на всіх рівнях російської мови, а це, у свою чергу, сприяло формуванню у суспільстві і області, і республіки в цілому, ставлення до українського як до меншовартісного, позначалося на свідомості жителів області, сприяло скороченню тих, хто ідентифікував себе як українець i збільшенню частики тих, хто ідентифікував себе як росіянин. Це засвідчили матеріали переписів населення 1959 та 1989 років. Вони зафіксували в області на тлі цілеспрямованої русифікаторської культурно-демографічної політики партійно-державного керівництва СРСР зменшення кількості населення 3 рідною українською мовою. Частка населення області, що вважало рідною українську мову скоротилася за цей час на $11,5 \%, 3$ 73,0 \% до 61,5 \%, при майже аналогічному зростанні тих, хто вважав російську своєю рідною мовою - $326,0 \%$ до $37,2 \%$. При цьому частка населення, що вважало рідними інші мови зменшилася лише на 0,3 \% (від 1,3 \% у 1959 до 1 \% у 1989 р.) (Дністрянський., 2008. с. 78).

Тобто це свідчило, що область внаслідок політики держави поступово еволюціонувала від переважно монолінгвістичної до білінгвістичної. Звуження мовного середовища саме української етнічної більшості області засвідчило неорганічність процесів та велику роль деструктивної державної політики у напрямку саме русифікації регіону.

\section{Висновки}

Отже, з середини 1940-х і до кінця 1980-х pр. у Дніпропетровській області спостерігався перманентний процес поширення російської мови. Серед причин, що зумовили дію такої тенденції, головною була національна політика правлячої партії, яка у своїй діяльності керувалася пріоритетами як партії Росії, а не партії союзу національних республік. Іншим, вагомим чинником виступало масштабне промислове будівництво у містах області, яке супроводжувалося широким залучення значних людських мас 3 різних територій країни та урбанізацією регіону, поширенням російської мови як мови міжнаціонального спілкування. Поєднання цих двох факторів сприяло масштабному втіленню російської мови у всі сфери виробничого, адміністративноуправлінського, культурного, повсякденного життя області, міжособистісного спілкування у побуті і на виробництві, визначило русифікацію закладів вищої, середньої спеціальної та професійної освіти, загальноосвітньої школи, дитячих дошкільних закладів. Російська стала для більшості міського населення області мовою повсякденного спілкування. Виросли покоління, для яких вона вже була їх рідною мовою. Аналогічні тенденції почали проявлятися i в сільському середовищі. Процес русифікації супроводжувався проявами зневаги до національної історії, культури, сприйняттям всього українського як меншовартісного. А це вже свідчило про небезпечні ознаки денаціоналізації жителів регіону та республіки загалом. 


\section{БІБЛІОГРАФІЧНІ ПОСИЛАННЯ}

Бажан О. Входження Кримської області до складу УРСР: освітянський аспект. Украйна ХХ ст.: культура, ідеологія, політика. 2014. Вип. 19. С. 165-175.

Бажан О. Г. Рух за поширення української мови в період «хрущовської відлиги». Наукові записки НаУКМА. Iсторичні науки 2007. Том 65. С. 40-49. 1999.

Баран В. К., Даниленко В. М. Україна в умовах системної кризи (1946-1980-ті рр.). Київ : Альтернативи,

Державний архів Дніпропетровської області. Ф. 416. Оп. 2. Спр.1024.

Державний архів Російської Федерації. Ф. 9396. Оп. 5. Спр. 1418.

Дзюба І. Інтернаціоналізм чи русифікація? Київ : Києво-Могилян. акад., 2005.

Дністрянський М. С. Етнографія України. Львів : Видавничий центр ЛНУ, 2008.

Закон «Про зміцнення зв'язку школи з життям і про дальший розвиток системи народної освіти в Українській РСР», ухвалений першою сесією Верховної Ради УРСР п’ятого скликання 17 квітня 1959 р. Радянська Украӥна. 1959. 19 квітня. №92 (11441). С.2-3.

Історія Дніпровського національного університету імені Олеся Гончара. 1918-2018 / Голова редкол. член.кор. НАН України, проф. М. В. Поляков. 5-е вид., переробл. і доп. Дніпро : Ліра, 2018.

Історичний факультет Дніпровського національного університету імені Олеся Гончара (1918-2018) / Світленко С. I. (голова редкол.) та ін. Дніпро : Ліра, 2020.

Кем был по национальности Леонид Брежнев. Рамблер. URL: https://news.rambler.ru/other/37758380-kembyl-po-natsionalnosti-leonid-brezhnev/

Ковалева Ф. Ф. Жизнь проведенная в могиле. Исповедь археолога. Дніпро : Ліра, 2008.

Масенко Л. Мовна політика в УРСР: історія лінгвоцид. Передмова до «Українська мова у ХХ сторіччі: історія лінгвоциду. Документи і матеріали. За ред. Л. Масенко. Київ : Вид. дім Києво-Могилянська академія, 2005.

Особистий архів автора Спогади Безручко Г. Т.

Особистий архів автора. Спогади Гурша P. I.

Особистий архів автора. Спогади Кучерявого I. П.

Особистий архів автора. Спогади Нікілєва О.Ф.

Особистий архів автора. Спогади Шамрай Л. О.

Русифікація України. Вікіпедія. URL: https://uk.wikipedia.org/wiki/\%D0\%A0\%D1\%83\%D1\%81\%D0\%B8\% D1\%84\%D1\%96\%D0\%BA\%D0\%B0\%D1\%86\%D1\%96\%D1\%8F_\%D0\%A3\%D0\%BA\%D1\%80\%D0\%B0\%D1\% $97 \% \mathrm{D} 0 \% \mathrm{BD} \% \mathrm{D} 0 \% \mathrm{~B} 8$.

Смольніцька М. Становище української мови в кінці 1950-х pр: за листами громадян до органів влади. Украӥна ХХ ст.: культура, ідеологія, політика: Зб. ст. 2014. Вип. 19. С. 114-130.

Українська мова в СРCP. Вікіпедія. URL: https://uk.wikipedia.org/wiki/\%D0\%A3\%D0\%BA\%D1\%80\%D0\% B0\%D1\%97\%D0\%BD $\%$ D $1 \% 81 \%$ D $1 \% 8 \mathrm{C} \% \mathrm{D} 0 \% \mathrm{BA} \% \mathrm{D} 0 \% \mathrm{~B} 0 \% \mathrm{D} 0 \% \mathrm{BC} \% \mathrm{D} 0 \% \mathrm{BE} \% \mathrm{D} 0 \% \mathrm{~B} 2 \% \mathrm{D} 0 \% \mathrm{~B} 0 \% \mathrm{D} 0 \% \mathrm{~B}$ 2 2 $\%$ D0\%A $1 \% \mathrm{D} 0 \% \mathrm{~A} 0 \% \mathrm{D} 0 \% \mathrm{~A} 1 \% \mathrm{D} 0 \% \mathrm{~A} 0$

Центральний державний архів вищих органів влади і управління України (далі - ЦДАГОУ). Ф. 1. Оп. 3. Спр. 2447.

ЦДАГОУ. Ф. 1. ОП. 24. Спр. 4796.

ЦДАГОУ. Ф. 1. Оп. 31. Спр. 369.

Шевченко С. М.Розвиток шкіл з російською мовою навчання у контексті диференціації загальної середньої освіти в УРСР (50-60-ті роки ХХ ст.) Проблеми сучасного підручника. 2014. Вип. 14. С. 833-842.

Ярмоленко М. Мовна політика в УРСР у 40-80-х роках ХХ століття. Наукові записки Інститутуполітичних і етнонаціональних досліджень ім. I. Ф. Кураса НАН України. 2013. Вип. 3. С. 365-377.

Ярмоленко М. Політико-правовий та соціально-регіональний контекст функціонування української мови в незалежній Україні. Україна: культурна спадщина, національна свідомість, державність. 2012. Вип. 21. С. 839-848.

Шкільництво в Україні Вікіпедія. URL: https://uk.wikipedia.org/wiki/Шкільництво_в_Україні

\section{REFERENCES}

Bazhan, O. (2014). Vkhodzhennia Krymskoi oblasti do skladu URSR: osvitianskyi aspect [Entry of the Crimean region into the USSR: educational aspect]. Ukraina XX st.: kultura, ideolohiia, polityka - Ukraine of the XX century: culture, ideology, politics, 19, 165-175 [in Ukrainian].

Bazhan, O. H. (2007). Rukh za poshyrennia ukrains'koi movy v period «khruschovs'koi vidlyhy» [Movement for the spread of the Ukrainian language during the «Khrushchev thaw»]. Naukovi zapysky NaUKMA. Istorychni nauky NaUKMA Research Papers. History, 65, 40-49 [in Ukrainian].

Baran, V. K., \& Danylenko V. M. (1999). Ukraina v umovakh systemnoi kryzy (1946-1980-ti rr) [Ukraine in the conditions of systemic crisis (1946-1980)]. Kyiv: Al'ternatyvy [in Ukrainian].

Derzhavnyj arkhiv Dnipropetrovs'koi oblasti [State Archives of Dnipropetrovs'k region]. Found 416. Inventory 2. File 1024 [in Ukrainian].

Derzhavnyj arkhiv Rosijs'koi federatsii [State Archives of the Russian Federation]. Found. 9396. Inventory 5. File 1418 [in Russian]. 
Dziuba, I. (2005). Internatsionalizm chy rusyfikatsiia? [Internationalism or Russification]. Kyiv: Kyievo-Mohylian. akad. [in Ukrainian].

Dnistrians'kyj, M. S. (2008). Etnohrafiia Ukrainy [Ethnography of Ukraine]. L'viv: Vydavnychyj tsentr LNU [in Ukrainian].

«On Strengthening the Link between School and Life and on the Further Development of the Public Education System in the Ukrainian SSR» was adopted by the first session of the Verkhovna Rada of the Ukrainian SSR of the fifth convocation on April 17, 1959. (1959, April 19). Radians'ka Ukraina, 92 (11441), 2-3 [in Ukrainian].

Poliakov, M. V. (Ed.). (2018). Istoriia Dniprovs'koho natsional'noho universytetu imeni Olesia Honchara. 1918-2018 [History of Oles Honchar Dnipro National University. 1918-2018]. 5th ed. Dnipro: Lira [in Ukrainian].

Svitlenko, S. I. (Ed.). (2020). Istorychnyj fakul'tet Dniprovs'koho natsional'noho universytetu imeni Olesia Honchara (1918-2018) [Faculty of History of Oles' Honchar Dnipro National University (1918-2018)]. Dnipro: Lira [in Ukrainian].

Kovaleva, F. F. (2008). Zhyzn' provedennaia v mohyle. Yspoved' arkheoloha [Life spent in the grave. Confession of an archaeologis]. Dnipro: Lira [in Ukrainian].

Masenko, L. (Ed.). (2005). Mova u XX storichchi: istoriia linhvotsydu. Dokumenty i materialy [Language policy in the USSR: the history of linguocide. Preface to Ukrainian language in the twentieth century: the history of linguocide. Documents and materials]. L. Masenko (Ed.).Kyiv: Kyiv-Mohyla Academy House [in Ukrainian].

Osobystyj arkhiv avtora. Spohady Bezruchko H. T. [Personal archive of the author. Memories Bezruchko H. T.] [in Ukrainian].

Osobystyj arkhiv avtora. Spohady Hursha R. I. [Personal archive of the author. Memories Hursha R. I.] [in Ukrainian]. Osobystyj arkhiv avtora. Spohady Kucheriavoho I. P. [Personal archive of the author. Memories Kucheriavyi I. P.] [in Ukrainian]

Osobystyj arkhiv avtora. Spohady Nikilieva O. F. [Personal archive of the author. Memories Nikiliev O. F.] [in Ukrainian].

Osobystyj arkhiv avtora. Spohady Shamraj L. O. [Personal archive of the author. Memories Shamraj L. O.] [in Ukrainian].

Smol'nits'ka M. (2014). Stanovysche ukrains'koi movy v kintsi 1950-kh rr: za lystamy hromadian do orhaniv vlady [The camp of the Ukrainian movi in the 1950s era: behind the sheets of hulks to the organs of power]. Ukraina XX st.: kul'tura, ideolohiia, polityka - Ukraine of the XX century: culture, ideology, politics, 19, 114-130 [in Ukrainian].

Tsentral'nyj derzhavnyj arkhiv vyschykh orhaniv vlady i upravlinnia Ukrainy [The Central State Archives of the Government and Administration of Ukraine (hereinafter - CSAGAU)]. Found 1. Inventory 3. File 2447 [in Ukrainian].

CSAGAU. Found 1. Inventory 24. File 4796 [in Ukrainian].

CSAGAU. Found. 1. Inventory 31. File 369 [in Ukrainian].

Shevchenko, S. M. (2014). Rozvytok shkil z rosiiskoiu movoiu navchannia u konteksti dyferentsiatsii zahalnoi serednoi osvity v URSR (50-60-ti roky XX st.) [Development of schools with Russian as the language of instruction in the context of differentiation of general secondary education in the USSR (50-60s of the XX century). Problemy suchasnoho pidruchnyka - Problems of a Modern Textbook, 14, 833-842 [in Ukrainian].

Yarmolenko, M. (2013). Movna polityka v URSR u 40-80-kh rokakh XX stolittia [Language policy in the USSR in the 40-80s of the twentieth centur]. Naukovi zapysky Instytutu politychnykh i etnonatsional'nykh doslidzhen' im. I. F. Kurasa NAN Ukrainy - Scientific Notes, 3, 365-377 [in Ukrainian].

Yarmolenko, M. (2012). Polityko-pravovyj ta sotsial'no-regional'nyj kontekst funktsionuvannia ukrains'koi movy v nezalezhnij Ukraini [Political-legal and socio-regional context of the functioning of the Ukrainian language in independent Ukraine]. Ukraina: kul'turna spadschyna, natsional'na svidomist', derzhavnist' - Ukraine: Cultural Heritage, National Identity, Statehood, 21, 839-848 [in Ukrainian].

Kem byl po natsyonalnosty Leonyd Brezhnev [Who was Leonid Brezhnev by nationality]. Rambler. Retrieved from https://news.rambler.ru/other/37758380-kem-byl-po-natsionalnosti-leonid-brezhnev/ [in Ukrainian].

Rusyfikatsiia Ukrainy [Russification of Ukraine]. Retrieved from https://uk.wikipedia.org/wiki/\%D0\%A0\%D1\%83 $\%$ D1\%81\%D0\%B8\%D1\%84\%D1\%96\%D0\%BA\%D0\%B0\%D1\%86\%D1\%96\%D1\%8F_\%D0\%A3\%D0\%BA $\%$ D $\%$ D $\% 8$ $0 \% \mathrm{D} 0 \% \mathrm{~B} 0 \% \mathrm{D} 1 \% 97 \% \mathrm{D} 0 \% \mathrm{BD} \% \mathrm{D} 0 \% \mathrm{~B} 8$ [in Ukrainian].

Ukrainska mova v SRSR [Ukrainian language in the USSR]. Retrieved from https://uk.wikipedia.org/wiki/\%D0\%A $3 \% \mathrm{D} 0 \% \mathrm{BA} \% \mathrm{D} 1 \% 80 \% \mathrm{D} 0 \% \mathrm{~B} 0 \% \mathrm{D} 1 \% 97 \% \mathrm{D} 0 \% \mathrm{BD} \% \mathrm{D} 1 \% 81 \% \mathrm{D} 1 \% 8 \mathrm{C} \% \mathrm{D} 0 \% \mathrm{BA} \% \mathrm{D} 0 \% \mathrm{~B} 0 \_\% \mathrm{D} 0 \% \mathrm{BC} \% \mathrm{D} 0 \% \mathrm{BE} \% \mathrm{D} 0$ $\% \mathrm{~B} 2 \% \mathrm{D} 0 \% \mathrm{~B} 0 \_\% \mathrm{D} 0 \% \mathrm{~B} 2 \_\% \mathrm{D} 0 \% \mathrm{~A} 1 \% \mathrm{D} 0 \% \mathrm{~A} 0 \% \mathrm{D} 0 \% \mathrm{~A} 1 \% \mathrm{D} 0 \% \mathrm{~A} 0$ [in Ukrainian].

Shkilnytstvo v Ukraini [Schooling in Ukraine] Retrieved from https://uk.wikipedia.org/wiki/Шкільництво в Україні [in Ukrainian].

\section{Nikiliev Oleksandr}

Dr. Sc., Full Prof., https://orcid.org/0000-0002-9918-3999, o_nikilev@i.ua 